\title{
Implementasi Pembelajaran Matematika Realistik untuk Peningkatan Hasil Belajar Siswa
}

\author{
Nurhafni \\ Sekolah Dasar Negeri 1 Langsa \\ nurafni@gmail.com
}

\begin{abstract}
The purpose of this study was to determine the improvement of mathematics learning outcomes in fractional material by applying realistic mathematics learning in class IV.B SD Negeri 1 Langsa. The research method used is Classroom Action Research (CAR) with two cycles. The research subjects were conducted in class IV.B in 2014/2015. The location of the research was carried out at SD Negeri 1 Langsa. From the results of the study, it was found that there was an increase in learning outcomes in fractional material using realistic mathematics learning for grade IV.B students at SD Negeri 1 Langsa. Where the increase in the class average value of 60.92 in the pre-cycle rose to 76.05 in the first cycle and rose to 85.21 in the second cycle. At the end of the learning process, the students were very active and there was a change in student understanding for the better so that student learning outcomes increased, thus it can be concluded that the application of realistic mathematics learning to fractions material can improve learning outcomes for grade IV.B students at SD Negeri 1 Langsa. So it is suggested that teachers can use realistic mathematics learning when teaching mathematics learning.
\end{abstract}

Keywords: Fractions, Learning Outcomes, Realistic Mathematics Learning.

\begin{abstract}
Abstrak
Tujuan penelitian ini yaitu untuk mengetahui peningkatan hasil belajar matematika pada materi pecahan dengan menerapkan pembelajaran matematika realistik di kelas IV.B SD Negeri 1 Langsa. Metode penelitian yang digunakan menggunakan Penelitian Tindakan Kelas (PTK) dengan dua siklus. Subjek penelitian dilakukan di kelas IV.B pada tahun 2014/2015. Adapun lokasi penelitian dilakukan di SD Negeri 1 Langsa. Dari hasil penelitian didapat bahwa terdapat peningkatan hasil belajar pada materi pecahan dengan menggunakan pembelajaran matematika realistik bagi siswa kelas IV.B SD Negeri 1 Langsa. Dimana peningkatan nilai ratarata kelas yaitu 60,92 pada pra siklus naik menjadi 76,05 pada siklus I dan naik menjadi 85,21 pada siklus II. Pada akhir pembelajaran siswa sudah sangat aktif dan terjadi perubahan pemahaman siswa menjadi lebih baik sehingga hasil belajar siswa meningkat, dengan demikian dapat disimpulkan bahwa dengan penerapan pembelajaran matematika realistik pada materi pecahan dapat meningkatkan hasil belajar bagi siswa kelas IV.B SD Negeri 1 Langsa. Sehingga disarankan agar guru-guru dapat menggunakan pembelajaran matematika realistic pada saat mengajar pembelajaran matematika.
\end{abstract}

Kata kunci: Hasil Belajar, Pecahan, Pembelajaran Matematika Realistik 


\section{A. Pendahuluan}

Pendidikan merupakan salah satu upaya untuk meningkatkan taraf kehidupan manusia. Pendidikan merupakan faktor yang penting peranannya di dalam proses kehidupan dan perkembangan suatu bangsa. Di negara yang sedang berkembang seperti Indonesia, peningkatan kualitas pendidikan harus terus ditingkatkan, baik kurikulum pembelajaran, tenaga pendidik, maupun strategi pembelajaran di dalam kelas yang terkait dengan persiapan guru dalam melaksanakan proses belajar-mengajar. Dalam hal ini guru merupakan komponen utama dalam upaya peningkatan mutu pendidikan dan sumber daya manusia. Guru sebagai ujung tombak dalam upaya peningkatan mutu pendidikan dituntut kreativitasnya untuk mencari berbagai metode dan strategi yang tepat untuk meningkatkan minat murid dan ketuntasan hasil belajar.

Kenyataan yang terjadi di lapangan masih banyak murid yang menganggap pelajaran matematika sulit sehingga banyak materi pelajaran tidak dikuasai dengan baik. Hal ini dapat diketahui dari hasil ulangan harian, sebagian besar nilai siswa masih dibawah kriteria ketuntasan minimal (KKM) yaitu 75 sedangkan rata-rata kelas sebesar 60,92. Hal ini bisa terjadi karena tidak adanya strategi yang dilakukan oleh guru agar para muridnya bisa menyukai matematika. Oleh karenanya peneliti mencoba untuk menggunakan pendekatan baru dalam upaya mengatasi permasalahan-permasalahan yang terjadi saat ini yaitu menerapkan pendekatan realistik.

Pembelajaran melalui pendekatan realistik merupakan salah satu alternatif dalam perbaikan kualitas pembelajaran matematika. Gravemeijer (Vidia, 2007) menyatakan bahwa dalam mendesain pembelajaran matematika realistik terdapat tiga prinsip dasar, yaitu: (1) Penemuan kembali secara terbimbing dan proses matematisasi secara progresif (guided reinvention and progressive mathematizing, (2) Fenomena yang bersifat mendidik (didactical phenomenology) situasi dimana topik matematika yang diberikan diterapkan untuk dua alasan yaitu pertama: menyatakan berbagai kegunaan yang harus 
diantisipasi dalam perintah, kedua: mempertimbangkan kecocokan sebagai pengaruh yang kuat untuk proses matematika progresif, (3) Mengembangkan model sendiri (self-developed models).

Dalam PMR, prosedur standar diajarkan setelah membiarkan murid melakukan prosedur informal, sehingga dalam proses belajar dimulai dengan situasi dimana model matematika diperoleh dari penjumlahan yang berulang. Graveimeijer (Mukhlis, 2005) mengemukakan 5 karakteristik pendekatan realistic yaitu menggunakan masalah kontekstual (the use of contex), Menggunakan model (the use models, bridging by vertical instruments), menggunakan kontribusi murid (student contribution), Proses pengajaran yang interaktif (Interactivity).

Dalam pembelajaran ini murid mempunyai kesempatan untuk menemukan kembali setiap penguasaan matematika atau pengetahuan matematika formal. kemudian, setiap siswa diberi kesempatan mengaplikasikan konsep-konsep matematika untuk memecahkan masalah sehari-hari atau masalah dalam bidang lain. Pembelajaran matematika selama ini sangat berbeda dengan pembelajaran matematika selama ini yang cenderung berorientasi kepada memberi informasi dan menggunakan matematika yang siap pakai (read made) untuk memecahkan masalahmasalah (Musliana, 2007).

Pecahan merupakan materi yang penting di sekolah dasar, karena merupakan dasar dalam belajar matematika lebih lanjut. Selain itu juga banyak digunakan dalam kehidupan sehari-hari dan dalam bidang ilmu lain. Berdasarkan informasi yang peneliti peroleh kebanyakan murid mengalami kesulitan dalam menyelesaikan soal-soal yang terkait dengan pecahan. Guru dalam pembelajarannya di kelas tidak mengaitkan materi pecahan dengan kehidupan sehari-hari dan murid kurang diberikan kesempatan untuk menemukan dan mengkonstruksikan sendiri ide-idenya. Ini merupakan salah satu penyebab kegagalan murid dalam memahami materi pecahan. 


\section{B. Metode}

Adapun pendekatan yang digunakan dalam penulisan ini adalah pendekatan kualitatif dengan jenis penelitian adalah penelitian tindakan kelas (PTK). Pendekatan kualitatif adalah berusaha mengungkapkan gejala secara menyeluruh dan sesuai dengan konteks melalui pengumpulan data dari latar alami (Arikunto, 2006). Lokasi Penelitian dilaksanakan di SD Negeri 1 Langsa beralamat Jl. Cut Nyak Dhien, Gp. Jawa, Langsa kota, Kota Langsa. Penelitian ini dilaksanakan selama 3 bulan yaitu dari bulan Februari sampai dengan bulan April 2015.

Subjek pada penelitian ini adalah murid kelas IV.B SD Negeri 1 Langsa, jumlah murid di dalam kelas adalah 38. Pada kelas IV.B dengan komposisi perempuan 15 siswa dan laki-laki 23 siswa. Prosedur Penelitian melaksanaan kegiatan belajar untuk setiap kali pertemuan dilakukan sesuai dengan siklus penelitian tindakan kelas (Action Research), yaitu perencanaan (planning), tindakan (acting), observasi (observing), refleksi (refleksi).

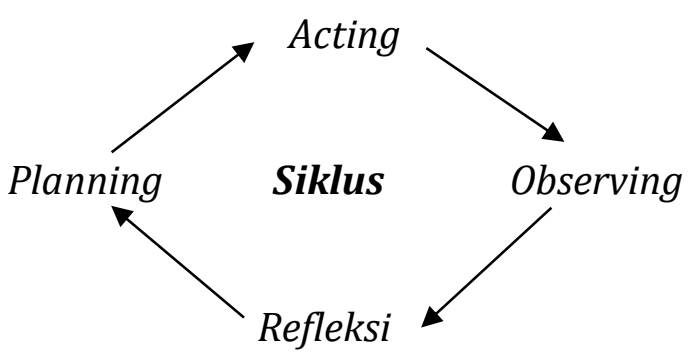

Gambar 1. Model Kurt Lewin (Arikunto, 2019)

a) Perencanaan; Pada tahap perencanaan, guru menyusun RPP, dan Media pembelajaran.

b) Tindakan; Lalu guru melakukan tindakan, yaitu melaksanakan kegiatan belajar mengajar sesuai dengan RPP yang telah dipersiapkan.

c) Observasi; Kemudian, peneliti melakukan observasi terhadap guru dan siswa pada proses pembelajaran yang berlangsung. 
d) Refleksi; Hasil refleksi yang diperoleh dijadikan pedoman untuk melakukan revisi terhadap berbagai kekurangan yang terdapat pada siklus I.

\section{Hasil dan Pembahasan}

\section{Hasil Tindakan Siklus I}

Hasil observasi pada siklus I dapat dideskripsikan seperti pada tabel 1 berikut ini. untuk memperjelas data hasil tes siklus I dapat dilihat pada tabel berikut ini

Tabel 1. Rekap hasil nilai tes siklus I

\begin{tabular}{cccccc}
\hline No & $\begin{array}{c}\text { Hasil } \\
\text { (Angka) }\end{array}$ & $\begin{array}{c}\text { Hasil } \\
\text { (Huruf) }\end{array}$ & Arti Lambang & $\begin{array}{c}\text { Jumlah } \\
\text { Siswa }\end{array}$ & Persen \\
\hline 1. & $85-100$ & A & Sangat baik & 8 & $21,05 \%$ \\
\hline 2. & $75-84$ & B & Baik & 19 & $50 \%$ \\
\hline 3. & $65-74$ & C & Cukup & 8 & $21,05 \%$ \\
\hline 4. & $55-64$ & D & Kurang & 3 & $7,90 \%$ \\
\hline 5. & $<54$ & E & Sangat kurang & - & $0 \%$ \\
\hline & & Jumlah & & 38 & $100 \%$ \\
\hline
\end{tabular}

Dari hasil tes tersebut, 27 murid sudah mencapai ketuntasan belajar dan 11 murid yang belum mencapai ketuntasan belajar. Data ketuntasan dapat dilihat dari tabel berikut ini :

Tabel 2. Ketuntasan Belajar Murid Hasil Tes Siklus I

\begin{tabular}{llcc}
\hline \multirow{2}{*}{ No } & \multirow{2}{*}{ Ketuntasan belajar } & \multicolumn{2}{c}{ Jumlah siswa } \\
\cline { 3 - 4 } & & 27 & Persen \\
\hline 1. & Tuntas & 11 & $71,05 \%$ \\
\hline 2. & Belum tuntas & 38 & $28,95 \%$ \\
\hline & Jumlah & $100 \%$
\end{tabular}

Berdasarkan persentase ketuntasan belajar maka 71,05\% dinyatakan sudah mencapai kriteria KKM, sedangkan 28,95\% belum mencapai KKM. Dan ini menjadi pertimbangan untuk dilakukan perbaikan. 


\section{Hasil observasi tindakan siklus I}

Guna kelancaran dalam melaksanakan penelitian dalam hal ini peneliti dibantu oleh dua orang pengamat (observer) yaitu teman sejawat. Hal yang diamati oleh pengamat dalam penelitian adalah kegiatan murid dan kegiatan guru selama proses pembelajaran berlangsung. Pemberian skor pada lembar observasi berdasarkan jumlah deskriptor yang muncul saat kegiatan berlangsung. Untuk lebih jelasnya, hasil observasi oleh pengamat terhadap kegiatan murid disusun dalam bentuk tabel 3 di bawah ini:

Tabel 3. Aktivitas Murid selama Kegiatan Pembelajaran

\begin{tabular}{lcc}
\hline \multicolumn{1}{c}{ Kategori Pengamatan } & \multicolumn{2}{c}{$\begin{array}{c}\text { Persentase Aktifitas Murid } \\
\text { dalam Pembelajaran (\%) }\end{array}$} \\
\cline { 2 - 3 } & RPP I & RPP II \\
\hline Mendengarkan/memperhatikan penjelasan guru/teman. & 52,38 & 44,44 \\
\hline $\begin{array}{l}\text { Membaca/memahami masalah di LKM. } \\
\text { Menyelesaikan masalah atau menemukan solusi } \\
\text { pemecahan masalah. }\end{array}$ & 13,49 & 4,76 \\
\hline $\begin{array}{l}\text { Membandingkan hasil temuan diskusi kelompok dengan } \\
\text { hasil diskusi kelompok lainnya. }\end{array}$ & 6,35 & 21,43 \\
\hline $\begin{array}{l}\text { Bertanya/menyampaikan pendapat/ide kepada guru atau } \\
\text { teman sekelompok. }\end{array}$ & 5,56 & 3,56 \\
\hline $\begin{array}{l}\text { Menarik kesimpulan suatu konsep yang ditemukan atau } \\
\text { suatu prosedur yang dikerjakan. }\end{array}$ & 2,38 & 1,59 \\
\hline \begin{tabular}{l} 
Perilaku yang tidak relevan dengan KBM. \\
\hline
\end{tabular} & 10,32 & 18,25 \\
\hline
\end{tabular}

Berdasarkan tabel 3. hasil pengamatan aktivitas murid dan mengacu pada kriteria waktu ideal aktivitas murid dalam pembelajaran maka dapat disimpulkan bahwa aktivitas murid untuk masing-masing kategori pada setiap RPP tidak efektif. Terutama pada kategori mendengarkan/memperhatikan penjelasan guru/teman dan perilaku yang tidak relevan dengan KBM.

Hal ini disebabkan karena dalam kegiatan pembelajaran masih terdapat beberapa siswa yang kurang aktif dan kurang bisa bekerja sama dengan kelompoknya, siswa lebih suka belajar sendiri sehingga anggota kelompok yang lain tidak diperdulikan sehingga ketika mereka mempresentasikan hasil diskusinya banyak anggota kelompok yang tidak bisa, 
ini diakibatkan karena kurangnya kerjasama antar anggota kelompok dan murid juga kurang terbiasa dalam mempresentasikan hasil diskusi, hal ini juga diperkuat dari hasil wawancara yang dilakukan peneliti dengan beberapa murid yang menyatakan bahwa mereka kurang bisa bekerjasama dengan kelompoknya, karena di dalam kelas biasanya murid belajar secara individu sementara sekarang mereka harus bekerja sama, sehingga masih ada rasa egois dan tidak mau mengalah pada diri murid, kemudian murid juga masih kebingungan dengan pembelajaran matematika realistik sehingga dalam menyelesaikan LKM murid masih terhambat.

Berikut ini adalah hasil pengamatan kemampuan guru mengelola pembelajaran matematika realistik:

Tabel 4. Observasi Guru Mengelola Pembelajaran Matematika Realistik

\begin{tabular}{|c|c|c|c|}
\hline No & Aspek yang diamati & RPP I & RPP II \\
\hline 1. & $\begin{array}{l}\text { Kemampuan mengajukan permasalahan kontekstual yang } \\
\text { dikenal murid dan sesuai dengan materi pelajaran. }\end{array}$ & 4 & 5 \\
\hline 2. & $\begin{array}{l}\text { Kemampuan menginfornasikan langkah-langkah } \\
\text { pembelajaran. }\end{array}$ & 4 & 5 \\
\hline 3. & $\begin{array}{l}\text { Kemampuan menggunakan alat peraga yang sesuai dengan } \\
\text { materi pelajaran. }\end{array}$ & 4 & 5 \\
\hline 4. & $\begin{array}{l}\text { Kemampuan menarik minat murid menerima pelajaran } \\
\text { dibandingkan pertemuan sebelumnya. }\end{array}$ & - & 5 \\
\hline 5. & $\begin{array}{l}\text { Kemampuan membimbing murid memahami } \\
\text { permasalahan realistik. }\end{array}$ & 4 & 5 \\
\hline 6. & Kemampuan memotivasi murid. & 4 & 5 \\
\hline 7. & $\begin{array}{l}\text { Kemampuan membantu murid menyelesaikan masalah } \\
\text { yang telah diajukan dengan: } \\
\text { a. Memandu diskusi } \\
\text { b. Mengajukan pertanyaan interaktif. } \\
\text { c. Menumbuhkan rasa percaya diri murid } \\
\text { d. Menghargai setiap jawaban murid. }\end{array}$ & $\begin{array}{l}4 \\
3 \\
4 \\
4\end{array}$ & $\begin{array}{l}5 \\
5 \\
5 \\
5\end{array}$ \\
\hline 8. & $\begin{array}{l}\text { Membantu murid mengembangkan sikap saling } \\
\text { menghargai terhadap perbedaan pendapat yang muncul. }\end{array}$ & 4 & 4 \\
\hline 9. & $\begin{array}{l}\text { Membantu murid menyimpulkan jawaban yang benar } \\
\text { dengan: } \\
\text { a. Mengarahkan dan memberi kesempatan menjawab } \\
\text { pertanyaan } \\
\text { b. Membantu murid mengembangkan sikap menghargai } \\
\text { teman }\end{array}$ & $\begin{array}{l}3 \\
4 \\
4\end{array}$ & $\begin{array}{l}4 \\
5 \\
4\end{array}$ \\
\hline
\end{tabular}




\begin{tabular}{llcc}
\hline No & \multicolumn{1}{c}{ Aspek yang diamati } & RPP I & RPP II \\
\hline c. $\quad \begin{array}{l}\text { Membantu murid mengembangkan sikap berbesar hati } \\
\text { d. } \quad \begin{array}{l}\text { Menciptakan situasi murid tidak merasa takut salah } \\
\text { atau ditertawakan }\end{array}\end{array}$ \\
e. $\begin{array}{l}\text { Memberi penguatan terhadap kesimpulan yang } \\
\text { diperoleh murid. }\end{array}$
\end{tabular}

Berdasarkan hasil pengamatan terhadap kemampuan guru mengelola pembelajaran dengan menggunakan PMR, menunjukkan bahwa nilai yang diperoleh guru dalam setiap aspek selama pertemuan pertama dan kedua adalah berkisar antara 4 sampai 5, maka dapat disimpulkan bahwa Nilai ini guru mampu mengelola pembelajaran pada kategori baik dan sangat baik berdasarkan kriteria yang telah ditetapkan.

Berdasarkan hasil wawancara kepada murid yang dilaksanakan setelah kegiatan pembelajaran selesai. Maka diketahui bahwa murid kurang bisa bekerjasama dengan kelompoknya, karena di dalam kelas biasanya murid belajar secara individu, sehingga masih ada rasa egois pada diri murid, kemudian murid juga masih kebingungan dengan pembelajaran matematika realistik sehingga dalam menyelesaikan LKM murid masih terhambat. Hasil wawancara juga digunakan sebagai bahan refleksi.

\section{Refleksi}

Setelah diberikan tindakan berupa PMR pada siklus I maka terlihat bahwa jumlah murid yang nilainya berada di bawah KKM semakin berkurang. Pada pra siklus jumlah murid yang di bawah KKM sebanyak 32 siswa dan pada akhir siklus I berkurang menjadi 11 siswa.

Tabel 5. Perbandingan Hasil Nilai Tes Prasiklus dan Siklus I

\begin{tabular}{llcc}
\hline \multirow{2}{*}{ No } & \multirow{2}{*}{ Hasil tes } & \multicolumn{2}{c}{ Jumlah siswa yang berhasil } \\
\cline { 3 - 4 } & & Pra siklus & Siklus I \\
\hline 1. & A (85-100) & - & 8 \\
\hline 2. & B (75-84) & 6 & 19 \\
\hline 3. & C (65-74) & 5 & 8 \\
\hline 4. & D (55-64) & 27 & 3 \\
\hline
\end{tabular}




\begin{tabular}{rcc}
\hline 5. $\quad \mathrm{E}(<54)$ & - & - \\
\hline Jumlah & 38 & 38 \\
\hline
\end{tabular}

Peningkatan ketuntasan belajar murid tampak pada tabel di bawah ini, jika dibandingkan hasil pra siklus dan siklus I dapat dilihat pada tabel berikut:

Tabel 6. Perbandingan Ketuntasan Belajar Murid Hasil Pra Siklus dengan Siklus I

\begin{tabular}{llcccc}
\hline \multirow{2}{*}{ No } & \multirow{2}{*}{ Ketuntasan Belajar } & \multicolumn{4}{c}{ Jumlah siswa } \\
\cline { 3 - 6 } & & \multicolumn{2}{c}{ Pra siklus } & \multicolumn{2}{c}{ Siklus I } \\
\cline { 3 - 6 } & & Jumlah & Persen & Jumlah & Persen \\
\hline 1. & Tuntas & 6 & $15,79 \%$ & 27 & $71,05 \%$ \\
\hline 2. & Belum tuntas & 32 & $84,21 \%$ & 11 & $28,95 \%$ \\
\hline & Jumlah & 38 & $100 \%$ & 38 & $100 \%$ \\
\hline
\end{tabular}

Berdasarkan data pada tabel 6 di atas dapat disimpulkan bahwa penggunaan pembelajaran matematika realistik mampu meningkatkan hasil belajar murid khususnya pada materi pecahan. Hal ini dapat dilihat dari kenaikan jumlah murid yang tuntas, pada pra siklus murid yang tuntas sebanyak 6 murid (15,79\%) sedangkan pada siklus I naik menjadi 27 murid $(71,05 \%)$.

Rata-rata nilai murid juga mengalami kenaikan, di prasiklus rata-rata nilai murid sebesar 60,92 sedangkan disiklus I naik menjadi 76,05. Walaupun sudah mengalami kenaikan seperti tersebut di atas, namun hasil tersebut belum optimal. Hal ini dapat dilihat dari hasil observasi aktivitas murid berdasarkan tabel hasil pengamatan dan mengacu pada kriteria waktu ideal aktivitas murid dalam pembelajaran maka dapat disimpulkan bahwa aktivitas murid untuk masing-masing kategori pada setiap RPP adalah tidak efektif. Terutama pada kategori mendengarkan/memperhatikan penjelasan guru/teman dan perilaku yang tidak relevan dengan KBM.

Ini disebabkan karena kurangnya kerjasama antar anggota kelompok dan murid juga kurang terbiasa dalam mempresentasikan hasil diskusi, hal ini juga diperkuat dari hasil wawancara yang dilakukan peneliti dengan beberapa murid yang menyatakan bahwa mereka kurang bisa bekerjasama dengan 
kelompoknya, karena di dalam kelas biasanya murid belajar secara individu sementara sekarang mereka harus bekerja sama, sehingga masih ada rasa egois dan tidak mau mengalah pada diri murid, kemudian murid juga masih kebingungan dengan pembelajaran matematika realistik sehingga dalam menyelesaikan LKM murid masih terhambat.

Sedangkan hasil penelitian data yang diperoleh dari hasil pengamatan kemampuan guru mengelola pembelajaran menunjukkan bahwa nilai yang diperoleh guru dalam setiap aspek selama tiga kali pertemuan adalah berkisar antara 4 sampai 5 . Nilai ini mencapai kategori kemampuan guru mengelola pembelajaran baik dan sangat baik berdasarkan kriteria yang telah ditetapkan.

Dengan melihat kelemahan-kelemahan yang terjadi pada siklus I maka guru harus lebih optimal dalam mengayomi murid agar mau bekerja sama dengan murid yang lain, guru juga harus menjelaskan indahnya hidup dan bekerja sama antar sesama murid dan guru harus lebih detail dalam menjelaskan langkah-langkah dalam pembelajaran matematika realistik karena pembelajaran ini merupakan pembelajaran baru yang diterapkan guru, sehingga diharapkan pada siklus yang ke II pembelajaran akan lebih baik lagi.

\section{Hasil Tindakan Siklus II}

\section{a. Hasil Tes Siklus II}

Hasil observasi pada siklus II dapat dideskripsikan seperti pada tabel berikut ini. untuk memperjelas data hasil tes siklus pertama dapat dilihat pada tabel berikut ini :

Tabel 7. Rekap Hasil Nilai Tes Siklus II

\begin{tabular}{cccccc}
\hline No & $\begin{array}{c}\text { Hasil } \\
\text { (Angka) }\end{array}$ & $\begin{array}{c}\text { Hasil } \\
\text { (Huruf) }\end{array}$ & Arti Lambang & $\begin{array}{c}\text { Jumlah } \\
\text { Siswa }\end{array}$ & Persen \\
\hline 1. & $85-100$ & A & Sangat baik & 18 & $47,37 \%$ \\
\hline 2. & $75-84$ & B & Baik & 17 & $44,73 \%$ \\
\hline 3. & $65-74$ & C & Cukup & 3 & $7,90 \%$ \\
\hline 4. & $55-64$ & D & Kurang & - & $0 \%$ \\
\hline 5. & $<54$ & E & Sangat kurang & - & $0 \%$ \\
\hline
\end{tabular}


Berdasarkan hasil analisis dalam bentuk tabel di atas, menunjukkan bahwa jumlah murid yang mendapat nilai A (sangat baik) sejumlah 47,37\% atau sebanyak 18 murid, yang mendapat nilai B (baik) sebesar 44,73\% atau sebanyak 17 murid, dan yang mendapat nilai C (cukup) sebesar 7,90\% atau sebanyak 3 murid, dan yang mendapat nilai D (kurang) dan E (sangat kurang) tidak ada. Ketuntasan belajar pada siklus II dapat ditabulasikan pada tabel berikut ini:

Tabel 8. Ketuntasan belajar murid hasil tes siklus II

\begin{tabular}{llcc}
\hline \multirow{2}{*}{ No } & \multirow{2}{*}{ Ketuntasan belajar } & \multicolumn{2}{c}{ Jumlah siswa } \\
\cline { 3 - 4 } & & 35 & \multicolumn{2}{c}{ Siklus II } \\
\cline { 3 - 4 } 1. & Tuntas & Jumlah & $92,10 \%$ \\
\hline 2. & Belum tuntas & 3 & $7,90 \%$ \\
\hline & Jumlah & 38 & $100 \%$ \\
\hline
\end{tabular}

Berdasarkan pada tabel 8, diketahui murid yang mencapai ketuntasan sebanyak 35 murid (92,10\%), sedangkan yang belum tuntas sebanyak 3 murid $(7,90 \%)$.

\section{b. Hasil observasi siklus II}

Pelaksanaan tindakan siklus II telah sesuai dengan rencana pembelajaran yang dibuat karena murid telah terbiasa belajar dalam situasi secara berkelompok sehingga kegiatan tersebut sudah terlihat aktif dan baik. Kegiatan observasi terhadap kegiatan murid dilakukan oleh seorang pengamat yaitu guru kelas lainnya. Hasil observasi terhadap kegiatan peneliti dapat dilihat pada tabel 9 berikut :

Tabel 9. Aktivitas Murid selama Kegiatan Pembelajaran

\begin{tabular}{ccc}
\hline Kategori Pengamatan & \multicolumn{2}{c}{$\begin{array}{c}\text { Persentase Aktifitas Murid } \\
\text { dalam Pembelajaran (\%) }\end{array}$} \\
\cline { 2 - 3 } & RPP II & RPP III \\
\hline
\end{tabular}




\begin{tabular}{lcc}
\hline $\begin{array}{l}\text { Mendengarkan/memperhatikan } \begin{array}{l}\text { penjelasan } \\
\text { guru/teman. }\end{array} \\
\text { Membaca/memahami masalah di LKM. }\end{array}$ & 13,59 \\
\hline $\begin{array}{l}\text { Menyelesaikan masalah atau menemukan solusi } \\
\text { pemecahan masalah. }\end{array}$ & 15,08 & 13,49 \\
\hline $\begin{array}{l}\text { Membandingkan hasil temuan diskusi kelompok } \\
\text { dengan hasil diskusi kelompok lainnya. }\end{array}$ & 1,59 \\
\hline $\begin{array}{l}\text { Bertanya/menyampaikan pendapat/ide kepada } \\
\text { guru atau teman sekelompok. }\end{array}$ & 6,35 \\
\hline $\begin{array}{l}\text { Menarik kesimpulan suatu konsep yang ditemukan } \\
\text { atau suatu prosedur yang dikerjakan. }\end{array}$ & 3,17 \\
\hline \begin{tabular}{l} 
Perilaku yang tidak relevan dengan KBM. \\
\hline
\end{tabular} & 8,73 \\
\hline
\end{tabular}

Berdasarkan tabel 9 hasil pengamatan aktivitas murid dan mengacu pada kriteria waktu ideal aktivitas murid dalam pembelajaran maka dapat disimpulkan bahwa aktivitas murid untuk masing-masing kategori pada setiap RPP adalah kurang efektif. Terutama pada kategori mendengarkan/memperhatikan penjelasan guru/teman dan perilaku yang tidak relevan dengan KBM. Ini disebabkan karena kekurangan pada peneliti yang kurang dapat mengontrol murid yang mempunyai semangat luar biasa. Antusias murid ketika presentasi, aktivitas murid ketika proses pembelajaran berlangsung.

Berikut ini adalah hasil pengamatan kemampuan guru mengelola pembelajaran matematika realistik:

Tabel 10. Hasil Pengamatan Kemampuan Guru Mengelola Pembelajaran Matematika Realistik

\begin{tabular}{|c|c|c|c|}
\hline No & Aspek yang diamati & RPP III & RPP IV \\
\hline 1. & $\begin{array}{l}\text { Kemampuan mengajukan permasalahan } \\
\text { kontekstual yang dikenal murid dan sesuai dengan } \\
\text { materi pelajaran. }\end{array}$ & 5 & 5 \\
\hline 2. & $\begin{array}{l}\text { Kemampuan menginfornasikan langkah-langkah } \\
\text { pembelajaran. }\end{array}$ & 5 & 5 \\
\hline 3. & $\begin{array}{l}\text { Kemampuan menggunakan alat peraga yang } \\
\text { sesuai dengan materi pelajaran. }\end{array}$ & 5 & 5 \\
\hline 4. & $\begin{array}{l}\text { Kemampuan menarik minat murid menerima } \\
\text { pelajaran dibandingkan pertemuan sebelumnya. }\end{array}$ & 5 & 5 \\
\hline 5. & $\begin{array}{l}\text { Kemampuan membimbing murid memahami } \\
\text { permasalahan realistik. }\end{array}$ & 5 & 5 \\
\hline 6. & Kemampuan memotivasi murid. & 5 & 5 \\
\hline
\end{tabular}


7. Kemampuan membantu murid menyelesaikan masalah yang telah diajukan dengan:

a. Memandu diskusi $\quad 5 \quad 5$

b. Mengajukan pertanyaan interaktif $\quad 5 \quad 5$

c. Menumbuhkan rasa percaya diri pada murid 5

d. Menghargai setiap jawaban murid $\quad 5 \quad 5$

8. Membantu murid mengembangkan sikap saling 5 menghargai terhadap perbedaan pendapat yang muncul.

9. Membantu murid menyimpulkan jawaban yang benar dengan:
a. Mengarahkan dan memberi kesempatan murid menemukan sendiri jawaban
b. Membantu murid mengembangkan sikap menghargai teman
c. Membantu murid mengembangkan sikap berbesar hati
d. Menciptakan situasi murid tidak merasa takut 4 salah atau ditertawakan
e. Memberi penguatan terhadap kesimpulan yang diperoleh murid.

5
5
5
5
5

Berdasarkan hasil penelitian data yang diperoleh dari hasil pengamatan kemampuan guru mengelola pembelajaran PMR termasuk pada kategori baik (nilai 4) dan sangat baik (nilai 5). Dari hasil wawancara dapat diperoleh bahwa kebanyakan murid sudah memahami langkah-langkah dari pembelajaran matematika realistic sehingga mereka senang di dalam belajar dan mereka sangat senang belajar dengan menggunakan pembelajaran tersebut, sehingga mereka ingin selalu belajar dengan menggunakan pembelajaran tersebut khususnya pada materi yang sulit. Hasil wawancara juga digunakan sebagai bahan refleksi.

\section{c. Refleksi}

Berdasarkan hasil nilai pra siklus, siklus I dengan hasil tes kemampuan siklus II dapat diketahui bahwa pembelajaran dengan menggunakan pembelajaran matematika realistik dapat meningkatkan hasil belajar murid. 
Untuk lebih jelasnya pada tabel di bawah ini, dipaparkan hasil refleksi pada siklus II.

Tabel 11. Perbandingan Hasil Pra Siklus, Siklus I Dengan Siklus II

\begin{tabular}{ccccc}
\hline \multirow{2}{*}{ No } & \multirow{2}{*}{$\begin{array}{c}\text { Hasil tes } \\
\text { (dalam huruf) }\end{array}$} & Pra siklus & Siklus I & Siklus II \\
\cline { 3 - 5 } 1. & A $(85-100)$ & - & 8 & 18 \\
\hline 2. & B $(75-84)$ & 6 & 19 & 17 \\
\hline 3. & C $(65-74)$ & 5 & 8 & 3 \\
\hline 4. & D $(55-64)$ & 27 & 3 & - \\
\hline 5. & E $(<54)$ & - & - & - \\
\hline & Jumlah & 38 & 38 & 38 \\
\hline
\end{tabular}

Jika dibandingkan hasil pra siklus, siklus I dan siklus II, dapat dilihat peningkatan ketuntasan belajar murid dan nilai rata-rata pada tabel 12 . Berikut di bawah ini:

Tabel 13. Perbandingan Ketuntasan Belajar Pra Siklus, Siklus I, dan Siklus II

\begin{tabular}{lccccccc}
\hline \multirow{2}{*}{ No } & \multirow{2}{*}{ Ketuntasan } & \multicolumn{6}{c}{ Jumlah siswa } \\
\cline { 3 - 7 } & & \multicolumn{2}{c}{ Pra siklus } & \multicolumn{2}{c}{ Siklus I } & \multicolumn{2}{c}{ Siklus II } \\
\cline { 3 - 7 } & Jumlah & Persen & Jumlah & Persen & Jumlah & Persen \\
\hline 1. & Tuntas & 6 & $15,79 \%$ & 27 & $71,05 \%$ & 35 & $92,10 \%$ \\
\hline 2. & Belum tuntas & 32 & $84,21 \%$ & 11 & $28,95 \%$ & 3 & $7,95 \%$ \\
\hline & Jumlah & 38 & $100 \%$ & 38 & $100 \%$ & 38 & $100 \%$ \\
\hline
\end{tabular}

Berdasarkan data pada tabel di atas dapat disimpulkan bahwa penggunaan pembelajaran matematika realistik mampu meningkatkan hasil belajar murid khususnya pada materi pecahan . Hal ini dapat dilihat dari kenaikan jumlah murid yang tuntas, pada pra siklus murid yang tuntas sebanyak 6 murid (15,79\%), pada siklus I naik menjadi 27 murid $(71,05 \%)$ dan pada siklus II naik lagi menjadi 35 siswa (92,10\%). Rata-rata nilai murid juga mengalami kenaikan, di pra siklus rata-rata nilai murid sebesar 60,92, di siklus I naik menjadi 76,05 dan pada siklus II naik lagi menjadi 85,21. Sedangkan berdasarkan hasil observasi kegiatan pembelajaran murid sudah aktif dan kreatif dalam belajar, sudah terjadi kerjasama yang baik antar murid serta murid sudah bisa mempresentasikan hasil diskusi ke depan kelas dengan 
baik. Berdasarkan hasil wawancara murid sangat menyukai pembelajran matematika realistik dan mereka tidak kebingungan lagi dengan pembelajaran tersebut dan mereka juga sangat antusias belajar.

\section{E. Kesimpulan}

Berdasarkan penelitian ini dapat disimpulkan bahwa dengan penerapan pembelajaran matematika realistik dapat meningkatkan hasil belajar pada materi pecahan bagi murid kelas IV.B SD Negeri 1 Langsa. PMR juga cocok digunakan untuk membantu murid semangat belajar khususnya mata pelajaran matematika. Membuat suasana belajar semakin menyenangkan juga membangun sikap kerjasama yang baik di antara murid.

\section{DAFTAR PUSTAKA}

Arikunto, 2006. Prosedur Penelitian. Jakarta: Rineka Cipta.

Arikunto, 2019. Penelitian Tindakan Kelas. Jakarta: Bumi Aksara.

Asmin, 2008. Implementasi Pembelajaran Matematika Realistik 9PMR) dan Kendala yang Muncul di Lapangan, Jakarta: Depdiknas.

Depdiknas, 2006. Kurikulum Tingkat Satuan Pendidikan. Jakarta: Depdiknas.

Depdiknas, 2006. Kurikulum Tingkat Satuan Pendidikan. Jakarta: Depdiknas.

Mukhlis, 2005. Pembelajaran Matematika Realistik untuk Materi Pokok Perbandingan di Kelas VII SMP Negeri 1 Pallangga. Surabaya: Unusa.

Musliana, 2007. Pembelajaran Matematika Realistik pada Materi Bangun Ruang sisi Lengkung (BRSL) di kelas VIII SMP Negeri 18 Banda Aceh. In: Banda Aceh: FKIP Unsyiah.

Permendiknas, 2006. Standar Isis Satuan Pendidikan. Jakarta: KemendiknasDepdiknas.

Riduwan, 2010. Belajar Mudah Penelitian untuk Guru Karyawan dan Peneliti Muda. Bandung: Alfabeta.

Vidia, P. S., 2007. Interaksi Siswa dalam Pembelajaran Matematika Realistik pada Materi Keliling dan Luas Persegi Panjang di Kelas IV MIN Rukoh Banda Aceh. FKIP Unsyiah, Banda Aceh. 
